\title{
Serum Haptoglobin in Cases of Ischemic Heart Diseases
}

\author{
Ghazala Bilgrami, M.B.B.S.,* S. P. Tyagi, M.D.,** \\ and A. QAsim, M.Sc., Ph.D. (Biochemistry)***
}

\section{SUMmary}

Serum haptoglobin $(\mathrm{Hp})$ was estimated in 76 cases of ischemic heart diseases (IHD) and 151 healthy individuals. A statistically significant rise in $\mathrm{Hp}$ level was observed in IHD cases. The rise was independent on the age and blood type of the cases but was more predominent in males as compared to females.

The increase in $\mathrm{H}_{\mathrm{p}}$ level was noticed after the third day of coronary attack and peak level was obtained between the 7th to 9th day. $\mathrm{Hp}$ level was closely related to the degree of myocardial damage. No rise was seen in cases of angina whereas maximum rise was noticed in patients with multiple infarcts.

Hp phenotype pattern in IHD cases was not different from that of control cases.

\section{Additional Indexing Words :}

Haptoglobins Importance in myocardial infarct

GERUM haptoglobin level has been used as an indicator of the degree of $D$ activity of various diseases particularly those characterized by the tissue destruction, ${ }^{1,2}$ malignancy, ${ }^{3)}$ renal disorders, ${ }^{4)}$ and myocardial infarction. Increasing levels of haptoglobin ( $\mathrm{Hp}$ ) in ischemic heart diseases (IHD) have been observed by different workers ${ }^{5 /-9}$ and a close correlation between the Hp level and extent of heart damage has been reported.

The present communication deals with the observations on serum $\mathrm{Hp}$ level in cases of IHD and its diagnostic and prognostic significance in these cases.

From the Departments of Pathology and Biochemistry, Jawaharlal Nehru Medical College, Aligarh Muslim University, Aligarh (202 001), U.P., India.

* Demonstrator in Pathology

** Reader in Pathology

*** Research Fellow in Biochemistry Department

Address for reprint: Dr. (Mrs.) Ghazala Bilgrami, Department of Pathology, J.N. Medical College, AMU, Aligarh (202 001), U.P., India.

Received for publication November 12, 1979. 


\section{Material AND Methods}

Serum Hp level was estimated in 76 cases of IHD admitted to the Jawaharlal Nehru Medical College Hospital, Aligarh Muslim University, Aligarh and 151 cases of normal healthy individuals. The diagnosis of IHD was established on the basis of clinical history, EKG changes, and serum enzymes estimation.

Serum $\mathrm{Hp}$ level was cstimated spectrophotometrically by the method of Owen et al. ${ }^{10)}$ Hp phenotyping was done on polyacrylamide gel according to the method of Davis. ${ }^{11)}$

\section{Results}

Out of 76 patients 62 were males and 14 females. The serum $\mathrm{Hp}$ level in these cases as compared to that of control cases has been shown in Table $\mathrm{I}$. The rise in $\mathrm{Hp}$ level in IHD cases was found to be statistically significant $(\mathrm{p}<0.05)$. Hp level was not related to the age and blood type of the cases but a significant difference was obtained between the $\mathrm{Hp}$ levels in cases of males (133.45 mg\% 141.82 ) and females (117 $\mathrm{mg} \% \pm 22.07)$. Thus in IHD cases a significant rise in $\mathrm{Hp}$ level was noticed in both sexes but it was more in males as compared to females.

Hp level and EKG changes:

A close correlation between the 2 was noticed (Fig. 1). In cases of angina pectoris with no EKG changes or of old or healed myocardial infarct no significant difference was observed in the value as compared to that of control cases $(p>0.05)$. But in cases of cardiac ischemia the values were significantly high and the rise was very much closely related to the extent of the cardiac damage. Maximum rise was seen in cases with multiple infarcts (average value being $171.47 \mathrm{mg} \%$ ) as compared to those with single infarct $(136.15 \mathrm{mg} \%$ ) and of myocardial ischemia $(115.28 \mathrm{mg} \%$ ). The difference in $\mathrm{Hp}$ levels in cases with different grades of EKG change was found to be sta-

Table I. Hp Level in Cases of IHD

\begin{tabular}{|c|c|c|c|c|}
\hline \multirow{2}{*}{ Cases } & \multirow{2}{*}{ Number } & \multicolumn{3}{|c|}{$\mathrm{Hp}_{\mathrm{p}} \quad(\mathrm{mg} / 100 \mathrm{ml})$} \\
\hline & & Range & Mean & S.D. \\
\hline 1. Male (IHD) & 62 & $80.0-366.6$ & 133.45 & 41.82 \\
\hline 2. Female (IHD) & 14 & $58.5-131.2$ & 117.26 & 22.07 \\
\hline 3. Total (IHD) & 76 & $80.0-366.6$ & 130.11 & 39.65 \\
\hline 4. Male (Control) & 126 & $54.3-175.0$ & 100.75 & 21.58 \\
\hline 5. Female (Control) & 25 & $58.5-131.2$ & 94.07 & 23.15 \\
\hline 6. Total (Control) & 151 & $54.3-175.0$ & 100.31 & 20.88 \\
\hline
\end{tabular}

$1: 2(\mathrm{p}<0.05), 1: 4(\mathrm{p}<0.05), 2: 5(\mathrm{p}<0.05), 3: 6(\mathrm{p}<0.05)$. 

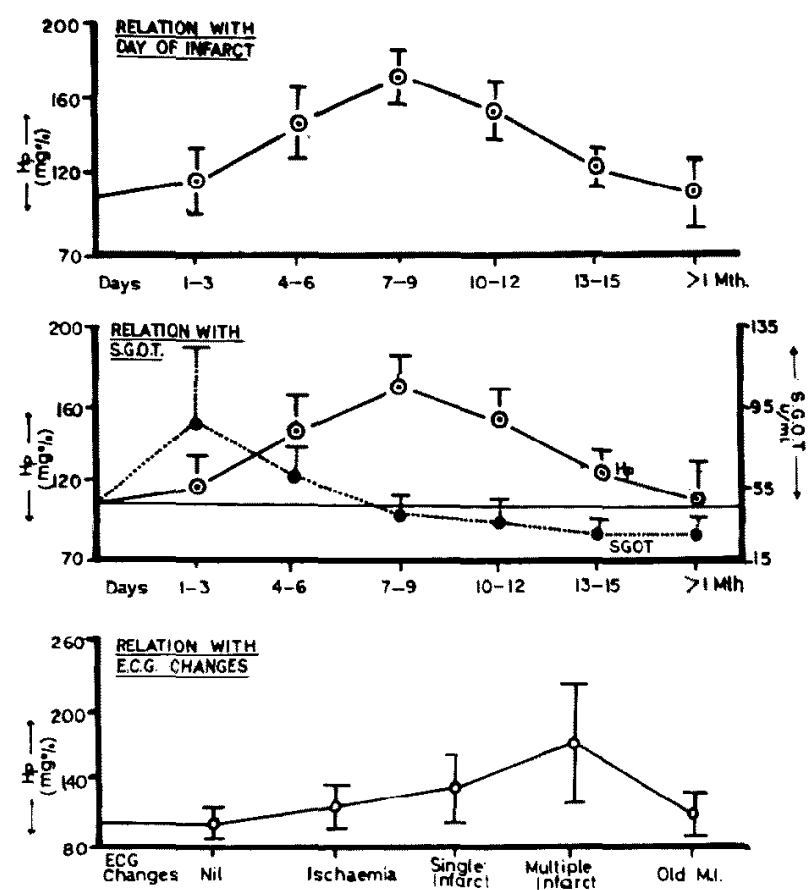

Fig. 1. Relationship between serum haptoglobin (Hp) level and day of infarct, SGOT and electrocardiographic changes in ischemie heart disease.

tistically significant $(\mathrm{p}<0.05)$.

$H p$ level in relation to the day of infarct and $S G O T$ levels:

No significant rise was noticed upto first 3 days, however, later on a gradual and significant rise was noticed reaching to a peak level between the 7 th and 9th day of the illncss (Fig. 1). The average value for $\mathrm{Hp}$ between the 7 th and 9 th day of infarct was $172.14 \mathrm{mg} \% \pm 15.93$. Thereafter a gradual fall was observed and the normal values were again obtained after a month in most of the cases.

In 11 cases repeated estimations of $\mathrm{Hp}$ level at frequent intervals also showed the same pattern i.e. a peak rise between the 7 th to 9 th day and then a gradual fall (Fig. 2). In 1 case $\mathrm{Hp}$ level was estimated after 4 months and the value was $86 \mathrm{mg} \%$. Out of 8 cases admitted in cardiogenic shock, 2 cases with $\mathrm{Hp}$ level above $200 \mathrm{mg} \%$ on the 7 th day expired whereas those below $200 \mathrm{mg} \%$ survived.

No definite correlation was seen between the Hp level and SGOT values. It can only be said that the significant rise of Hp level was noticed after the third day, when the SGOT value had already started receeding.

Hp phenotyping :

Hp phenotyping was done on polyacrylamide gel in 40 cases of IHD 


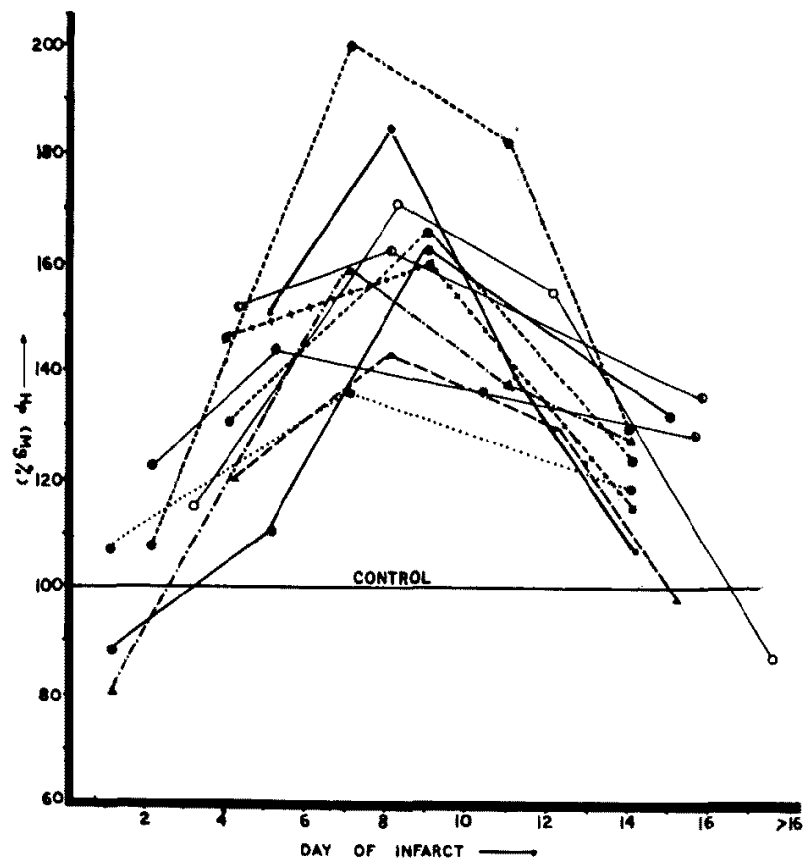

Fig. 2. Relation of serum haptoglobin level $(\mathbf{H p})$ and day of infarct in ischemic heart disease.

Table II. Hp Types in Cases of IHD

\begin{tabular}{l|c|c|c|c|c|c|c}
\hline \multirow{2}{*}{ Cases } & \multirow{2}{*}{ Number } & \multicolumn{3}{|c|}{ Hp phenotype } & \multicolumn{2}{c}{ Hp frequency } \\
\cline { 2 - 8 } & & $1-1$ & $2-1$ & $2-2$ & $H^{1}$ & $H^{2}$ \\
\hline IHD cases & 40 & $2(5.00)$ & $8(20.00)$ & $30(75.00)$ & 0.150 & 0.850 \\
Control cases & 50 & $2(4.00)$ & $8(16.00)$ & $40(80.00)$ & 0.120 & 0.880
\end{tabular}

and 50 control cases. The genotype frequency of $\mathrm{Hp}^{1}$ and $\mathrm{Hp}^{2}$ was 0.150 and 0.850 respectively as compared to those of control cases $(0.120$ and 0.880 respectively). No significant difference was found in the distribution of various phenotypes in 2 categories of cases (Table II).

\section{Discussion}

In the present study a rise in the Hp level was noticed in cases of IHD as had also been observed by others ${ }^{5,61,12)}$ though the peak level was observed on different days. Owen et $\mathrm{al}^{5)}$ noticed the peak level on the third day of coronary attack but Agostoni et $\mathrm{a}^{8), 13)}$ have reported a rise of $\mathrm{Hp}$ level from the third day and the peak level reaching on the 6th day and values returning to normal in about 2 months. The observations in the present study were in 
conformity with those of Agostoni et al. ${ }^{8)}$

The rise of $\mathrm{Hp}$ level was more in male patients as compared to females though in control cases Hp level was more or less the same in either sex. This disparity could be accounted for by the hormonal make up of the females which provided a protective role against IHD hence the incidence of the disease as well as its severity is low in females as compared to their male counterparts. ${ }^{14)}$

The increase in $\mathrm{Hp}$ level was closely related to the EKG changes (Fig. 1). These results correlated well with the observations of Agostoni et al ${ }^{8)}$ but were contrary to the findings of Bisariya et $\mathrm{al}^{9)}$ who failed to get any close relationship between the rise of $\mathrm{Hp}$ level and extent of cardiac damage.

Conflicting views have been expressed about the rise of $\mathrm{Hp}$ in cases of IHD. Jayle and Coumel ${ }^{15}$ ) were the first to report high level of $\mathrm{Hp}$ in IHD cases and considered that inflammation of the arterial wall was responsible for the rise of these proteins. Their views were further supported by others. ${ }^{16), 17)}$ Agostoni et $\mathrm{al}^{8)}$ on the other hand have suggested that the tissue injury is responsible for stimulating liver for excess production of this protein to be utilized in the process of healing at the site of infarct. Hence the peak level was seen on the 6 th day when the healing was maximum. The observations of the present study (a peak level on the 7 th to 9 th day) also support the views of Agostoni et al. ${ }^{8}$. The excess protein liberated by the liver is entrapped within the injured tissue and provides the supporting background for the scar formation.

The relative risk of myocardial infarction in $\mathrm{Hp}_{\mathrm{p}} 1-1$ individuals was 1.33 as compared to $\mathrm{Hp} 2-2$ individuals. Thus no genetic predisposition to the disease process is noticed as far as $\mathrm{Hp}$ is concerned.

The authors came to the conclusion that estimation of $\mathrm{Hp}$ level in cases of IHD as such had no diagnostic importance but an increase in $\mathrm{Hp}$ level was very much closely related to the extent of tissue damage and thus $\mathrm{Hp}$ estimation could be used for prognostic purpose.

\section{ACKNOWLEDGMENT}

The authors are very much grateful to Dr. Salahuddin, Professor in Biochemistry, J.N. Medical College, A.M.U., Aligarh for his valuable guidance in compiling the work.

\section{REFERENCES}

1. Murray RF, Robinson JC, Dublin TD, Elaine LP: Haptoglobin and rheumatic fever. Brit Med J I: 762, 1966 
2. Bogdanovich L: Serum haptoglobin as an index of the activity of pulmonary tuberculosis. Probl Tuberk 46: 65, 1968

3. Mueller WK, Handschumacher R, Wade ME: Serum haptoglobins in patients with ovarian malignancies. Obst \& Gynec 38: 427, 1971

4. Nyman M: Serum haptoglobin. Methodological and clinical studies. Scand J Clin Lab Invest 11 (Suppl 39): 1, 1959

5. Owen JA, Smith R, Padanyi R, Martin J: Serum haptoglobins in disease. Clin Sci 26: 1, 1964

6. Jayle MF, Poumailloux, Maruy A: Interet du dosage de l'haptoglobins et du seromucoide dhez les malades atteints de coronarite obliterante. Cah Coll Med Paris 6: 3, 1965

7. Jayle MF, Choubrac P, Drosdowsky MA, Jacot P: Valour semilogigue du trauxde l'haptoglobine et du seromucoide dans les affections coronariennes. Presse Med 76: 1805, 1968

8. Agostoni A, Vergani C, Stabilini R, Marsini B, Arcidiacono R, Binaghi PC: Immunochemical quantitation of acute phase reactive proteins in M.I. Am Heart J 80: 313, 1970

9. Bisariya BN, Vasavada PS, Mukerjee DP: Serum haptoglobin in coronary artery disease. Indian Heart $\mathrm{J}$ 22: 246, 1970

10. Owen JA, Better FC, Hoban J: A simple method for the determination of serum haptoglobin. J. Clin Path 13: 163, 1960

11. Davis BJ: Disc electrophoresis by polyacrylamide gel. Annals NY Acad Sci 121: 404, 1964

12. Bachmann GW, Weiss ME, Rapp W: Differenziette quantitative serum eiweissbest immungen in ablauf des herzinfarktes. Schweiz Med Wschr 98: 1825, 1968

13. Agostoni A, Binaghi C, Radice F, Stabilini R: Acute phase protein and healing of M.I. J Mol Cell Cardiol 4: 519, 1972

14. Friedberg CK: Coronary heart disease. Other diseases of coronary artery. in Diseases of Heart, WB Saunders Co Ltd, London, p645, 1966

15. Jayle MF, Coumel H: Les modifications dela formule proteique du serum dans l'infarctus du myocarde. Arch Mal Coeur et Vaisseaux 4: 328, 1952

16. Genda A: Studies on atherosclerosis with reference to acid mucopolysaccharides. Jap Circulat J 30: 560, 1966

17. Sanwald R, Ritz E, Hugh B: Research on mucopolysaccharides in normal and athcrosclerotic arteries. J Atherosclerosis Res 8: 433, 1968 